\title{
Effects of ocean acidification on the dissolution rates of reef- coral skeletons
}

Ocean acidification threatens the foundation of tropical coral reefs. This study investigated three aspects of ocean acidification: (i) the rates at which perforate and imperforate coralcolony skeletons passively dissolve when $\mathrm{pH}$ is 7.8 , which is predicted to occur globally by 2100 , (ii) the rates of passive dissolution of corals with respect to coral-colony surface areas, and (iii) the comparative rates of a vertical reef-growth model, incorporating passive dissolution rates, and predicted sea-level rise. By 2100 , when the ocean $\mathrm{pH}$ is expected to be 7.8, perforate Montipora coral skeletons will lose on average $15 \mathrm{~kg} \mathrm{CaCO}_{3} \mathrm{~m}^{-2}$ year-1, which $^{-1}$ is approximately $-10.5 \mathrm{~mm}$ of vertical reduction of reef framework per year. This rate of passive dissolution is higher than the average rate of reef growth over the last several millennia and suggests that reefs composed of perforate Montipora coral skeletons will have trouble keeping up with sea-level rise under ocean acidification. Reefs composed of primarily imperforate coral skeletons will not likely dissolve as rapidly, but our model shows they will also have trouble keeping up with sea-level rise by 2050 . 


\section{Effects of ocean acidification on the dissolution 3 rates of reef-coral skeletons}

4 Robert van Woesik*1, Kelly van Woesik ${ }^{2}$, Liana van Woesik ${ }^{2}$, 5 Sandra van Woesik ${ }^{2}$

${ }^{1}$ Florida Institute of Technology ph: +1 321674 7475; Fax: +1 3216747238

${ }^{2}$ Melbourne, Florida, USA

*Correspondence to: rvw@fit.edu

11 Key Words: Corals, dissolution, acidification, reef growth, climate change. 
13 Ocean acidification threatens the foundation of tropical coral reefs. This study investigated three

14 aspects of ocean acidification: (i) the rates at which perforate and imperforate coral-colony 15 skeletons passively dissolve when $\mathrm{pH}$ is 7.8 , which is predicted to occur globally by 2100 , (ii) the 16 rates of passive dissolution of corals with respect to coral-colony surface areas, and (iii) the 17 comparative rates of a vertical reef-growth model, incorporating passive dissolution rates, and 18 predicted sea-level rise. By 2100, when the ocean $\mathrm{pH}$ is expected to be 7.8 , perforate Montipora 19 coral skeletons will lose on average $15 \mathrm{~kg} \mathrm{CaCO}_{3} \mathrm{~m}^{-2}$ year ${ }^{-1}$, which is approximately $-10.5 \mathrm{~mm}$ 20 of vertical reduction of reef framework per year. This rate of passive dissolution is higher than the 21 average rate of reef growth over the last several millennia and suggests that reefs composed of 22 perforate Montipora coral skeletons will have trouble keeping up with sea-level rise under ocean 23 acidification. Reefs composed of primarily imperforate coral skeletons will not likely dissolve as 24 rapidly, but our model shows they will also have trouble keeping up with sea-level rise by 2050. 


\section{Introduction}

\section{Ocean acidification}

27 As humans continue to burn fossil fuels at an unprecedented rate, the concentration of carbon

28 dioxide $\left(\mathrm{CO}_{2}\right)$ in the atmosphere is presently higher than it has been for the last 420,000 years

29 (Petit et al. 1999; Hansen et al. 2006; Hoegh-Guldberg et al. 2007). The oceans uptake a large

30 proportion of the atmospheric $\mathrm{CO}_{2}$, increasing the concentrations of both carbonic acid and

31 bicarbonate ions, and reducing the concentration of carbonate ions, shifting the ocean's acid-base

32 balance toward a lower pH (Broeker 1983; Caldeira and Wickett 2003; Silverman et al. 2009).

33 The increase in ocean acidification directly threatens calcifying marine organisms, such as reef-

34 building corals and the myriad of species that rely on corals for protection and sustenance

35 (Hoegh-Guldberg et al. 2007; Rodolfo-Metalpa et al. 2011).

36 The oceanic $\mathrm{pH}$ has already decreased by $0.1 \mathrm{pH}$ units since the 18 th century, and is expected to

37 drop by another $0.2-0.4 \mathrm{pH}$ units by 2100 . Yet the oceans are not homogenous in regard to rates

38 of reductions in carbonate ions. Although warm waters increase reaction rates, thermodynamic

39 principles and Henry's Law tells us that cool temperate and polar waters absorb asymmetrically

40 more $\mathrm{CO}_{2}$ than tropical waters, and are therefore closer to unity than the more super-saturated

41 tropical waters (Broecker 1983). Yet the tropical oceans are changing at a more rapid rate and are

42 acidifying more quickly than the cooler waters most likely because of the relationship of rapidly

43 increasing ocean temperature and reaction rates (Zeebe et al. 2008). Moreover, the Pacific Ocean

44 is more acidic than the Atlantic Ocean, and shoaling saturation depth is around $500 \mathrm{~m}$ in the

45 Pacific and $4500 \mathrm{~m}$ in the Atlantic (Feely et al. 2004; Millero 2007). 
46 There is increasing evidence that ocean acidification, through the increase in the partial pressure

47 of carbon dioxide $\left(\mathrm{pCO}_{2}\right)$ and the subsequent changes in the concentration of carbonate and

48 bicarbonate ions, reduces rates of coral calcification, which are directly proportional to the

49 saturation state of aragonite in the shallow oceans (Langdon and Atkinson 2005). Other studies

50 have shown that calcification rates are proportional to the concentration of carbonate ions in the

51 water column (Anthony et al. 2008; Marubini et al. 2008). These studies are essentially

52 synonymous, however, because the aragonite and calcite saturation state $(\Omega)$ is the product of the

53 concentrations of calcium and carbonate ions divided by an equilibrium constant. Since the salt

54 concentration, including calcium ions, stemming from terrestrial weathering hasn't changed in

55 the oceans for over 1.5 billion years, the aragonite saturation state is essentially a measure of

56 carbonate ions in the oceans.

57 Perhaps more importantly is the strong interaction effects between temperature and ocean

58 acidification on coral calcification rates (Reynaud et al. 2003; Erez et al. 2010). Indeed, the

59 optimal window of physiological performance of a given marine species at a given temperature

60 will be narrowed under acidification (Portner 2010). Calcification of corals under ambient

61 temperature do not necessarily change with increased $p \mathrm{CO}_{2}$, but calcification decreases when

62 both temperature and $p \mathrm{CO}_{2}$ are elevated (Reynaud et al. 2003). Yet several studies have shown

63 that many corals are unaffected by external carbonate ion concentrations because they have the

64 capacity to up-regulate internal $\mathrm{pH}$ by actively exchanging internal hydrogen ions for calcium

65 ions through Ca-ATPase transportation (Al-Horani et al. 2003; Allemand 2004; McCulloch et al.

66 2012). By modifying their internal chemistry, live corals may buffer themselves from ocean

67 acidification. Coral skeletons, however, have no internal-buffering capacity because they are not 
68 protected by coral membranes (Rodolfo-Metalpa et al. 2011; Ries 2011). Coral skeletons are

69 instead subjected to the raw and immediate threats of ocean acidification and will be subjected to

70 dissolution when the ocean's $\mathrm{pH}$ declines.

\section{Accretion of coral reefs}

72 The accretion of coral reefs occurs over geological time periods when rates of calcium carbonate

$73\left(\mathrm{CaCO}_{3}\right)$ production exceed rates of destruction and dissolution (Neumann and MacIntyre 1985;

74 Buddemeier and Hopley 1988; Glynn 1997; Perry et al. 2013). The interaction between

75 production and destruction depends on the consistency of coral cover through time. For example,

76 where coral cover is consistently low, reef accretion is minimal (Neumann and MacIntyre 1985).

77 Most modern reefs, however, support little more than 28\% live coral cover (Bruno and Selig 78 2007), and are essentially veneers over pre-existing, antecedent foundations of $\mathrm{CaCO}_{3}$ (Adey

79 1978; Hopley 1982). For example, the Florida Keys only supported, on average, 2-3\% of live

80 coral cover in 2011 (Office of National Marine Sanctuaries 2011). Therefore, reefs with high

81 carbonate cover and few live corals are particularly vulnerable to ocean acidification.

82 The average modern, shallow seaward coral reef in the Indo-Pacific, with high coral cover, has

83 been estimated to produce about 4 kilograms of calcium carbonate per square meter of reef per

84 year, which equates with an upward reef-growth rate of approximately $3 \mathrm{~mm}$ per year (Smith and

85 Kinsey 1976). These estimates were based on alkalinity reduction techniques subjected to a pH of

86 8.2, equivalent to the $\mathrm{pH}$ of today's oceans. By 2100 the ocean's $\mathrm{pH}$ is expected to be 7.8, and we

87 hypothesize that the destructive processes associated with ocean acidification might outweigh the

88 constructive processes. The rates of dissolution of reef framework may however also depend on 
89 flow rates, the extent of cementation of reef framework, and on the porosity of corals and their

90 surface area.

\section{Reef cementation and coral porosity}

92 Reefs vary in porosity depending on both: (i) the local rates of sedimentation and the extent to 93 which those sediments become consolidated, or lithified, within the reef framework, and (ii) the

94 extent of cementation of the reef framework. Both processes depend in part on exposure to water-

95 flow rates (MacIntyre and Marshall 1988). High-energy, windward reefs consistently exposed to

96 large waves are generally more highly cemented than low-wave energy, leeward reefs because 97 mass-transfer rates influence rates of cementation. Cementation involves the infilling of intra98 skeletal pores with either Mg calcite or aragonite (MacIntyre and Marshall 1988). While the 99 extent of cementation affects the dislodgment of reef substrate and the tenacity of corals to 100 remain attached to reefs during storms (Madin et al. 2012), the extent of reef cementation may 101 also affect dissolution rates during ocean acidification because the infilling of pores by cements 102 decreases the surface area of exposure (Cubillas et al. 2005).

103 Reef corals also vary in porosity (Gladfelter 1982; Hughes 1987). Although all modern corals 104 secrete orthorhombic aragonite fusiform crystals, as small as 1-3 $\mu \mathrm{m}$ (Gladfelter 1982), corals 105 vary considerably in the arrangement of the crystals, which influences the internal surface area 106 that is exposed (Fig. 1). Fast-growing corals, such as Montipora and Acropora, are mostly 107 perforate corals (Gladfelter 1982), whereas slow-growing corals, such as Pectinia and 108 Symphyllia, are imperforate (Table 1). An extreme example of imperforate skeletons is evident by 109 the observation of occasional floating, massive Symphyllia colonies (DeVantier 1992). Because of 110 the fused nature of the dissepiments and their imperforate skeletons, gases are trapped in the 
111 septal chambers and upon dislodgement from reefs, for example during a storm, the colonies will

112 float. Perforate corals however, do not have the capacity to isolate septal chambers.

113 The internal porosity of coral skeletons, at the scale of $0.5-1 \mathrm{~mm}$ (Fig. 1), increases the

114 available surface area of chemical exchange and therefore increases the potential rates of

115 dissolution. Walter and Morse (1984) showed that rates of dissolution of skeletal carbonates were

116 inversely related to grain-size diameter and surface roughness, with fine grained carbonates

117 dissolving faster than large, rough surfaces. However, we should not discount the possibility that

118 perforate and imperforate corals also differ in other aspects, beyond the obvious differences in

119 porosity, and therefore we question whether surface area is a useful predictor of rates of passive

120 dissolution of both perforate and imperforate corals.

121 This study will examine whether the porosity and the surface area of coral skeletons will

122 influence their rate of dissolution when the ocean $\mathrm{pH}$ is 7.8, which is predicted to occur by 2100.

123 More specifically, we tested three hypotheses: (1) that perforate Montipora coral skeletons are

124 more likely to passively dissolve than imperforate Pectinia coral skeletons at a pH of 7.8, (2) that

125 the rates of passive dissolution of coral-colony skeletons are proportional to their surface areas,

126 and (3) future reef accretion rates under ocean acidification will differ depending on the nature of

127 the coral assemblages, with perforate coral assemblages unable to keep up with predicted sea-

128 level rise and imperforate coral assemblages faring a better chance at keeping up with sea-level

129 rise and ocean acidification. 


\section{Materials and Methods}

\section{Acidification experiments}

132 In order to test the first hypothesis, perforate Montipora colonies (Figure 1) and imperforate

133 Pectinia colonies without tissue (Figure 2) were used to make comparisons of weight loss when

134 immersed in seawater and held in zero-flow conditions (i.e., to test passive dissolution), and held 135 at a $\mathrm{pH}$ of 8.2 , equivalent to the $\mathrm{pH}$ of today's oceans, and compared with colonies held at a $\mathrm{pH}$ 136 of 7.8 , which is predicted to occur globally by 2100 . Fifteen skeletal samples $(\leq 5 \mathrm{~cm})$ of 137 Montipora spp. colonies and fifteen skeletal samples of Pectinia spp. were collected from the 138 fringing reefs of Okinawa, Japan in 2001. In order to test the second hypothesis, we used a 139 variety of growth forms of Montipora, including submassive, branching, encrusting, and foliose. 140 Colonies of Pectinia with different surface areas were used for experimental treatments, but all 141 samples were foliose because Pectinia is only found as foliose colonies on modern coral reefs.

142 Before $\mathrm{pH}$ treatments, the samples were placed in a drying oven at $40^{\circ} \mathrm{C}$ for $48 \mathrm{~h}$ and weighed $(\mathrm{g})$ 143 using a Sartorius Research Balance. Each treatment sample was then placed in a separate 144 container of seawater that was maintained at a $\mathrm{pH}$ of 7.8 by adding diluted acetic acid to match 145 the predicted $\mathrm{pH}$ of the seawater in the year 2100 (Intergovernmental Panel on Climate Change 146 [IPCC], 2007). The control samples were placed in seawater that was maintained at a $\mathrm{pH}$ of 8.2, 147 to match modern ocean conditions, and maintained at $24^{\circ} \mathrm{C}$ and a salinity of 35 . Total alkalinity 148 was not measured in this study. Seawater was changed every 2 days. After 7 days the samples 149 were rinsed and dried in a drying oven at $40^{\circ} \mathrm{C}$ for 48 hours, and re-weighed. The volume of each 150 coral sample $(\mathrm{mL})$ was calculated using a displacement method and the surface area of each coral 151 sample $\left(\mathrm{cm}^{2}\right)$ was calculated using a single wax-dipping method (Veal et al. 2010). 
153 The difference in dry weight $(\mathrm{g})$ before and after the acid treatment was calculated for each coral

154 sample. To correct for differences in initial weight, the loss of calcium carbonate was divided by 155 each coral's initial weight. To compare differences in dissolution rates that may have varied in 156 accordance with growth form, we undertook an analysis of variance (ANOVA) and a Tukey's 157 post-hoc test using R (R Development Core Team, 2012). The relationship between the surface 158 area, volume, and the loss of calcium carbonate was examined using curve fitting with Matlab ${ }$.

\section{Accretion-dissolution model}

160 The loss of calcium carbonate was extrapolated from the change in calcium carbonate per gram

$161 \mathrm{~cm}^{-2}$ day $^{-1}$, to the equivalent loss of calcium carbonate per $\mathrm{kg} \mathrm{m}^{-2} \mathrm{y}^{-1}$. This loss was compared with 162 the geological literature and converted to the approximate equivalent of vertical reduction of reef 163 framework in mm per year (Smith and Kinsey 1976). The loss was compared with predicted sea164 level rise (Vermeer and Rahmstorf 2009). In order to achieve this goal, the reef accretion rates 165 were modeled as an ordinary differential equation:

$$
\mathrm{dA} / \mathrm{d} t=(a . \mathrm{A}) / \mathrm{A}+b . \mathrm{S}-(c . \mathrm{D}) / \mathrm{A}
$$

where $\mathrm{A}$ is the accretion of a reef relative to time $(t) ; a$ is the accretion coefficient determined by

168 coral and coralline algal growth minus the bioerosion rates (input as $7 \mathrm{~mm}$ per year for reefs that 169 accrete the maximum of $10 \mathrm{~kg} \mathrm{CaCO}_{3} \mathrm{~m}^{-2} \mathrm{y}^{-1} ; 3 \mathrm{~mm}$ per year for reefs that accrete $4 \mathrm{~kg} \mathrm{CaCO}_{3} \mathrm{~m}^{-}$

$170{ }^{2} \mathrm{y}^{-1}$; and $0.75 \mathrm{~mm}$ per year for reefs that accrete $1 \mathrm{~kg} \mathrm{CaCO}_{3} \mathrm{~m}^{-2} \mathrm{y}^{-1}$, with a $50 \%$ average reef 171 porosity, after Kinsey 1979 and Smith 1983); $b$ is a coefficient for sedimentation (S), input as 1 
$172 \mathrm{~mm}$ per year for consistency; and $c$ is a coefficient for the dissolution (D) rates. The equations

173 were solved using Runge-Kutta methods using the ode45 solver in Matlab ${ }^{\circledR}$ (code is available in 174 the appendix).

175 The results of passive dissolution were input into our reef-growth model and compared with 176 projections of global sea-level rise, from 1990 to 2100 following Vermeer and Rahmstorf (2009), 177 which did not consider regional isostatic rebound effects, regional tectonics, and local land-use 178 effects. The sea-level rise projections used different IPCC (2007) emission scenarios, including

179 the $\mathrm{B} 1$ scenario representing a $+1.8^{\circ} \mathrm{C}$ global increase in temperature, the $\mathrm{A} 2$ scenario 180 representing a $+3.4^{\circ} \mathrm{C}$ global increase in temperature, and the $\mathrm{A} 1 \mathrm{~F} 1$ scenario representing a $4^{\circ} \mathrm{C}$ 181 global increase in temperature.

\section{Results}

183 There was a significant difference $(\mathrm{p}<0.0258)$ in coral skeleton weight loss that was dependent 184 on coral colony porosity (Figure 3). The skeletons of foliose, perforate Montipora coral colonies 185 passively dissolved significantly (post-hoc Tukey test, $\mathrm{p}<0.011$ ) faster than the skeletons of 186 foliose, imperforate Pectinia coral colonies (Figure 3). The skeletons of foliose Montipora corals 187 also lost more calcium carbonate than other Montipora growth forms (Figure 3). Foliose 188 Montipora corals also lost more calcium carbonate than other Montipora growth forms (Figure 189 3). There was a strong negative relationship between the surface area of Montipora corals and the 190 loss of calcium carbonate, suggesting that the larger the surface area of Montipora colonies the 191 more rapidly the corals dissolved (Figure 4). The rate of calcium carbonate loss followed the 192 equation, $\mathrm{CaCO}_{3}$ loss $=-0.005 \times$ exp ${ }^{0.017 * \text { surface area }}$. The loss of $\mathrm{CaCO}_{3}$ of perforate Montipora was 
193 approximately $0.000042 \mathrm{~g} \mathrm{CaCO}_{3} \mathrm{~cm}^{2}$ day- $^{-1}\left(-0.42 \mathrm{~g} \mathrm{CaCO}_{3} \mathrm{~m}^{-2} \mathrm{~d}^{-1}\right.$, or $\left.-15.3 \mathrm{~kg} \mathrm{CaCO}_{3} \mathrm{~m}^{2} \mathrm{y}^{-1}\right)$.

194 This loss in calcium carbonate is approximately equivalent to $-10.5 \mathrm{~mm}$ of vertical reduction of 195 reef framework per year.

196 In contrast, the skeletons of imperforate Pectinia colonies showed no consistent (passive) 197 dissolution at a $\mathrm{pH}$ of 7.8, suggesting that the loss of weight in low $\mathrm{pH}$ treatments was no 198 different than the weight loss in controls (Figures 3 and 5). There was no significant relationship 199 between the surface area of Pectinia coral colonies and their rate of passive dissolution (Figure 200 5). There was also no significant relationship between dissolution rates and the volume of either 201 Montipora or Pectinia colonies.

\section{Accretion-dissolution model}

203 The sea-level rise projections from 1990 to 2100 were constructed using different IPCC (IPCC 204 2007) emission scenarios, including the $\mathrm{B} 1$ scenario, representing a $+1.8^{\circ} \mathrm{C}$ global increase in 205 temperature, the $\mathrm{A} 2$ scenario representing a $+3.4^{\circ} \mathrm{C}$ global increase in temperature, and the $\mathrm{A} 1 \mathrm{~F} 1$ 206 scenario representing a $4^{\circ} \mathrm{C}$ global increase in temperature (Figure 6; Vermeer and Rahmstorf, 207 2009). These sea-level projections were compared with three different reef-building capacities in 208 conjunction with rates of perforate and imperforate coral skeletons (equation 1) under ocean 209 acidification (Figures 6 and 7). The model with high dissolution rates, which included perforate

210 skeletons, and consistently high coral cover $\left(10 \mathrm{~kg} \mathrm{CaCO}_{3} \mathrm{~m}^{-2} \mathrm{y}^{-1}\right)$ are not expected to keep up 211 with sea level rise under ocean acidification (Figure 6). By contrast, the model with low 212 dissolution rates, which included imperforate corals, could continue to grow reefs and keep up 213 with sea level rise, but only reefs consistently supporting high coral cover $\left(10 \mathrm{~kg} \mathrm{CaCO}_{3} \mathrm{~m}^{-2} \mathrm{y}^{-1}\right)$ 
214 and only to 2050. Around 2050, the model shows that the rates of sea level rise are expected to

215 increase faster than the rates at which corals can grow reefs (Figure 7).

\section{Discussion}

217 This study examined whether the destructive processes involving the dissolution of calcium 218 carbonate might over-ride the accretionary potential of coral reefs when the oceans $\mathrm{pH}$ drops to 2197.8 , which is predicted to occur by 2100 . We examined the rates of skeletal dissolution of two 220 Indo-Pacific corals, Montipora and Pectinia, subjected to a $\mathrm{pH}$ of 7.8. Rates of passive 221 dissolution were directly proportional to the surface area of corals, but only for the perforate 222 Montipora; dissolution was less predictable for the imperforate Pectinia. The average loss of 223 Montipora $\mathrm{CaCO}_{3}$ per surface area was $15.3 \mathrm{~kg} \mathrm{~m}^{-2} \mathrm{y}^{-1}$, which was 3 times more than the average 224 growth rates of modern reefs $\left(4 \mathrm{~kg} \mathrm{CaCO}_{3} \mathrm{~m}^{-2} \mathrm{y}^{-1}\right)$ (Smith 1983; Smith and Kinsey 1976; Kinsey 225 1979).

226 We should however, treat the comparative results between skeletal dissolution and reef growth, 227 with caution even though the units match $\left(\mathrm{CaCO}_{3} \mathrm{~m}^{-2} \mathrm{y}^{-1}\right)$. In the comparison above, our data 228 were extrapolated across at least five orders of magnitude spatially, from grams per $\mathrm{cm}^{2}$ to 229 kilograms per $\mathrm{m}^{2}$, and at least six orders of magnitude temporally, from skeletal dissolution over 230 weeks to reef growth over millennia. Yet our results, on the passive dissolution rates of porous 231 Montipora coral skeletons $\left(-0.42 \mathrm{~g} \mathrm{CaCO}_{3} \mathrm{~m}^{-2} \mathrm{~d}^{-1}\right)$ and the recent field results from Cyronak et al. 232 (2013), on the passive dissolution rates of carbonate sediments on Heron Island (Great Barrier 
233 Reef, Australia), are the same. Cyronak et al. (2013) also showed that adding flow to experiments

234 more than doubled dissolution rates because of advection processes.

235 We also note that Smith, Kinsey, and co-workers, originally calculated calcium carbonate 236 production using advection alkalinity reduction techniques that measured change in alkalinity 237 across reef flats over minutes. The maximum rate of modern reef growth has been estimated at $2389.6 \mathrm{~kg} \mathrm{CaCO}_{3} \mathrm{~m}^{-2} \mathrm{yr}^{-1}$ on a back-reef of Johnston Atoll $\left(16^{\circ} \mathrm{N}, 169^{\circ} \mathrm{W}\right)$, that supported "heavy" 239 coral cover (but the percentage coral cover was not provided in the original publication) (Kinsey 240 1979). Other estimates using X-radiographs and extrapolation techniques showed similar results, 241 ranging from $9 \mathrm{~kg} \mathrm{CaCO}_{3} \mathrm{~m}^{-2} \mathrm{y}^{-1}$ for reefs in the Caribbean with uncharacteristically high coral 242 cover (38\%) (Stearn et al. 1977), to less than $1 \mathrm{~kg} \mathrm{CaCO}_{3} \mathrm{~m}^{-2} \mathrm{y}^{-1}$ for reefs with low coral cover 243 (Dullo 2005).

244 Although our results show rapid rates of Montipora dissolution, modern-reef framework is not all

245 Montipora. Rates of carbonate dissolution will also depend on the type of coral assemblages that 246 are present on reefs and their densities. Globally, approximately 404 coral species are perforate, 247 and 432 are imperforate (Table 1), yet most Indo-Pacific reefs are dominated by Acropora, 248 Montipora, Porites, and faviids; and Caribbean reefs are dominated by Porites, Siderastrea, and 249 Orbicella. Therefore, most modern reefs are primarily supporting perforate corals, and these 250 corals have disproportionately contributed to vertical reef accretion through the Holocene (Veron 251 1995, Wood 1999).

252 Still, changing the $\mathrm{pH}$ of seawater is only one of the changes that will occur to reefs subjected to 253 climate change. Sea level will also rise with increasing global temperature (Smith and 
254 Buddemeier 1992; Vermeer and Rahmstorf 2009). The conservative estimates of sea-level rise

255 from the IPCC (2007), which did not consider ice-sheet dynamics, showed that sea level will 256 increase 20-60 $\mathrm{cm}$ by 2100 (approximately $4 \mathrm{~mm}$ a year). More recent estimates of sea level rise

257 by Vermeer and Rahmstorf (2009) predict a sea level increase of $75-90 \mathrm{~cm}$ by 2100 , which is

258 approximately $9 \mathrm{~mm}$ a year. Our predictive model, although extrapolating across several spatial 259 and temporal scales, showed that coral reefs composed of perforate skeletons and supporting few 260 live corals, will have trouble keeping up with sea level rise under ocean acidification. These 261 results, although tentative, suggest that more quantitative studies are necessary to determine the 262 potential of reefs to keep up with sea level rise by hierarchically quantifying the production 263 versus dissolution rates of reefs in relation to: (i) coral cover, (ii) coral-community composition, 264 (iii) habitat type, and (iv) the regional oceanography.

\section{Acknowledgments}

266 Our special thanks extend to Richard Turner, Biological Sciences Department, College of 267 Science, Florida Institute of Technology, for the use of his laboratory equipment and to Gayle 268 Duncan for preparing the scanning electron microscope images. The corals were collected at $269\left(26^{\circ} 21^{\prime} 34.47^{\prime \prime} \mathrm{N}, 127^{\circ} 44^{\prime} 20.96^{\prime \prime} \mathrm{E}\right)$ with a permit to Robert van Woesik from the Okinawan 270 prefectural government, Japan. 
272 Adey W.H. (1987) Coral reef morphogenesis: A multi-dimensional model, Science 202: 831-837

273 Al-Horani F.A., Al-Moghrabi S.M., de Beer D. (2003) The mechanism of calcification and its 274 relation to photosynthesis and respiration in the scleractinian coral Galaxea fascicularis, Marine 275 Biology 142: 419-426

276 Allemand D., Ferrier-Pagès C., Furla P., Houlbrèque F., Puverel S., Reynaud S., Tambutté E., 277 Tambutté S., Zoccola D. (2004) Biomineralisation in reef-building corals: from molecular 278 mechanisms to environmental control, Comptes Rendus Palevol 3: 453-467

279 Anthony K.R.N., Kline D.I., Diaz-Pulido G., Dove S., Hoegh-Guldberg O. (2008) Ocean 280 acidification causes bleaching and productivity loss in coral reef builders, Proceedings of the 281 National Academy of Science 105: 17442-17446

282 Broecker W.S (1983) The Ocean, Scientific American 249: 146-48

283 Bruno J.F., Selig E.R (2007) Regional decline of coral cover in the Indo-Pacific: timing, extent, 284 and subregional comparisons, PLoS ONE, 2, 8, e711. doi:10.1371/journal.pone.0000711

Buddemeier R.W., Hopley D (1988) Turn-ons and turn offs: Causes and mechanisms of the initiation and termination of coral reef growth, Proceedings of the $6^{\text {th }}$ International Coral Reef Symposium, Townsville, Australia, 8-12 August 1988, 1988, 1, 253-261

Caldera K., Wickett M.E. (2003) Anthropogenic carbon and ocean pH, Nature 425: 365

Cubillas P, Kohler S, Prieto M, Chairat C, Oelkers EH (2005) Experimental determination of the dissolution rates of calcite, aragonite, and bivalves. Chemical Geology 216: 59-77

291 Cyronak T, Santos IR, Eyre BD (2013) Permeable coral reef sediment dissolution driven by 292 elevated $p \mathrm{CO} 2$ and pore water advection. Geophysical Research Letters 40:1-6

293 DeVantier L.M (1992) Rafting of tropical marine organisms on buoyant coralla, Mar. Ecol. Prog. 294 Ser. 86, 301-302

295 Dullo W.C. (2005) Coral growth and reef growth: a brief review, Facies 51: 33-48

296 Erez J, Reynaud S, Silverman J, Schneider K, Allemand D (2010) Coral calcification under ocean 297 acidification and global change. In, Editors, Z. Dubinsky \& N Stambler, Coral reefs: an 298 ecosystem in transition, Springer, New York, $551 \mathrm{pp}$

299 Feely RA, Christopher L. Sabine CL, Lee K, Will Berelson W, Kleypas J, Fabry VJ, Frank J. $300 \quad$ Millero FJ (2004) Impact of Anthropogenic $\mathrm{CO}_{2}$ on the $\mathrm{CaCO}_{3}$ System in the Oceans. $301 \quad$ Science 305: 362-366

302 Fine M., Tchernov D (2007) Scleractinian coral species survive and recover from decalcification, 303 Science 315: 1811 
304 Gladfelter EH (1982) Skeletal development in Acropora cervicornis:I. patterns of calcium

305 carbonate accretion in the axial corallite. Coral Reefs 1:45-51

306 Glynn P.W (1997) Bioerosion and coral-reef growth: a dynamic balance, In Birkeland, C. (Ed.),

307 Life and Death of coral reefs, Chapman \& Hall, 68-95

308 Hansen L., Sato M., Ruedy R., Lo K., Lea D.W., Medina-Elizade M. (2006) Global temperature 309 change, PNAS 103: 14288-14293

310 Hoegh-Guldberg O., Mumby P., Hooten A.J., Steneck R.S., Greenfield P., Gomez E., Harvell

311 C.D., Sale P.F., Edward A.J., Caldiera K., Knowlton N., Eakin C.M., Iglesias-Prieto R., Muthiga

312 N., Bradbury R.H., Dubi A., Hatziolos M.E (2007) Coral reefs under rapid climate change and

313 ocean acidification, Science 318: 1737-1742

314 Hautmann M (2004) Effect of End-Triassic $\mathrm{CO}_{2}$ maximum on carbonate sedimentation and 315 marine mass extinction. Facies 50:257-261

316 Hopley D (1982) The geomorphology of the Great Barrier Reef: Quaternary development of 317 coral reefs, John Wiley-Interscience, New York, pp 453

318 Hughes TP (1987) Skeletal density and growth form of corals. Marine Ecology Progress Series 319 35: 259-266

320 Intergovernmental Panel on Climate Change (IPCC 2007), Climate Change 2007: the physical

321 science basis, Contribution of Working Group 1 to the Fourth Assessment Report of the

322 Intergovernmental Panel on Climate Change, Cambridge Univ. Press, Cambridge, p 793

323 Kinsey D.W (1979) Carbon turnover and accumulation by coral reefs, PhD Dissertation thesis,

324 University of Hawaii, 284

325 Kroeker K.J., Kordas R.L., Crim R.N., Singh G.G (2010) Meta-analysis reveals negative yet

326 variable effects of ocean acidification on marine organisms, Ecology Letters 13: 1419-1434

327 Langdon C., Atkinson M.J (2005) Effect of elevated $\mathrm{pCO}_{2}$ on photosynthesis and calcification of 328 corals and interactions with seasonal change in temperature/irradiance and nutrient enrichment, J.

329 Geophys. Res.110, C09S07, doi:10.1029/2004JC002576

330 MacIntyre I., Marshall J.F (1988) Submarine lithification in coral reefs: same facts and 331 misconceptions, Proc 6th Int. Coral Reef Symp., Australia, 1, 263-272

332 Madin JS, Hughes TP, Connolly SR (2012) Calcification, storm damage, and population 333 resilience of tabular corals under climate change. PLOS ONE 10.1371/journal.pone.0046637

334 Manzello D.P., Kleypas J.A., Budd D.A., Eakin C.M., Glynn P.W., Langdon C. (2008)

335 Proceedings of the National Academy of Sciences 105: 10450-10455 
336

337

338

339

340

341

342

343

344

345

346

347

348

349

350

351

352

353

354

355

356

357

358

359

360

361

362

363

364

365

366

367

368

369

370

371

372

Marubini F., Ferrier-Pages C., Furla P., Allemand D (2008) Coral calcification responds to seawater acidification: a working hypothesis towards a physiological mechanism, Coral Reefs 7 : 491-499

McCulloch M., Falter J., Trotter J., Montagna P (2012) Coral resilience to ocean acidification and global warming through $\mathrm{pH}$ up-regulation, Nature Climate Change, 2012, doi:

10.1038/NCLIMATE1473

Millero FJ (2007). The marine inorganic carbon cycle. Chem. Rev. 2007, 107, 308-341

Morse JW, Arvidson, RS, Luttge A (2007) Calcium Carbonate Formation and Dissolution. Chem. Rev. 107: 342-381

Neumann A.C., MacIntyre I (1985) Reef response to sea level rise: keep-up, catch-up or giveup, Proc. 5th International Coral Reef Congress, 3: 105-110

Office of National Marine Sanctuaries, Florida Keys National Marine Sanctuary Condition Report 2011, U.S. Department of Commerce, National Oceanic and Atmospheric Administration, Office of National Marine Sanctuaries, Silver Spring, MD, 2011, 105

Perry CT, Murphy GN, Kench PS, Smithers SG, Edinger EN, Steneck RS, Mumby PJ (2013).

Caribbean-wide decline in carbonate production threatens coral reef growth. Nature

Communications 4:1402. doi:10.1038/ncomms2409

Petit JR, Jouzel J, Raynaud D, Barkov NI, Barnola J.-M, Basile I, Bender M, Chappellaz J, Davis M, Delaygue G, Delmotte M, Kotlyakov VM, Legrand M, Lipenkov VY, Lorius C, Pepin L, Ritz C, Saltzman E, Stievenard M (1999) Climate and atmosphere history of the past 420,000 years from the Vostok ice core, Antartica. Nature 399: 429-436²

Portner H.-O (2010) Oxygen- and capacity-limitation of thermal tolerance: a matrix for integrating climate-related stressor effects in marine ecosystems. J Exp Biol 213:881-893

Reynaud S, Leclercq N, Romaine-Lioud S, Ferrier-Pagès C, Jaubert J, Gattuso J-P (2003) Interacting effects of $\mathrm{CO}_{2}$ partial pressure and temperature on photosynthesis and calcification in a scleractinian coral. Glob Change Biol 9:1660-1668

Ries J. (2011) Acid ocean cover up, Nature Climate Change 1: 294-295

Rodolfo-Metalpa R., Houlbrèque F., Tambutté E., Boisson F., Baggini C., Patti F.P., Jeffree R., Fine M., Foggo A., Gattuso J.P., Hall-Spencer J.M. (2011) Coral and mollusc resistance to ocean acidification adversely affected by warming, Nature Climate Change, doi: 10.1038/NCLIMATE1200

R Development Core Team (2012). R: A language and environment for statistical computing. $\mathrm{R}$ Foundation for Statistical Computing, Vienna, Austria. ISBN 3-900051-07-0, URL http://www.R-project.org. Silvermann J., Lazor B., Cao L., Caldiera K., Erez J. (2009) Coral reefs may start dissolving when atmospheric $\mathrm{CO}_{2}$ doubles, Geophysical Research Letters 36: L05606, doi:10.1029/2008GL036282 
373 Smith S.V. (1983) Coral reef calcification, In Barnes, D.G. (Ed.), Perspectives on coral reefs, 374 Brian Clouston Publisher, 240-247

375 Smith S.V., Kinsey D.W. (1976) Calcium carbonate production, coral reef growth, and sea level 376 change, Science 194, 937-939

377 Smith S.V., Buddemeier R.W. (1992) Global change and coral reef ecosystems, Annual Review 378 of Ecology and Systematics 23: 89-118

379 Stearn C.W., Scoffin T.P., Martindale W. (1977) Calcium carbonate budget of a fringing reef on 380 the west coast of Barbados, Bull. Marine Science 27: 479-510

381 Veal C.J., Carmi M., Fine M. (2010) Increasing the accuracy of surface area estimation using 382 single wax dipping of coral fragments. Coral Reefs 29: 893-897

383 Vermeer M., Rahmstorf S. (2009) Global sea level linked to global temperature, Proceedings of 384 the National Academy of Sciences 106, 21527-21532

385 Veron JEN (1995) Corals in space and time: the biogeography and evolution of the Scleractinia. 386 University of New South Wales Press, Sydney, pp 321

387 Veron JEN (2008) Mass extinctions and ocean acidification: biological constraints on geological 388 dilemmas. Coral Reefs 27: 459-472

389 Walter L.M., Morse J.W. (1984) Reactive surface area of skeletal carbonates during dissolution: 390 effect of grain size, J. of Sedimentary Petrology 54: 1081-1090

391 Wood R (1999) Reef evolution. Oxford University Press, Oxford, pp 414

392 Zeebe RE, JC Zachos, Caldira K, Tyrrell T (2008) Carbon emissions and acidification. Science 393 321: 51-52 
395 Figure 1. Montipora. Scanning electron microscope image of Montipora skeleton; scale bar is 396500 micrometer.

397 Figure 2. Pectinia. Scanning electron microscope image of Pectinia skeleton; scale bar is 500 398 micrometer.

399 Figure 3. Comparative loss of calcium carbonate. Loss of calcium carbonate, divided by the 400 initial weight (g), of four different coral growth forms of Montipora coral skeletons, and one 401 growth form of Pectinia coral skeleton, when exposed to $\mathrm{pH} 7.8$ seawater for 7 days. The graph 402 also depicts the controls for Montipora and Pectinia coral skeletons, which were exposed to 403 present-day seawater, at a $\mathrm{pH}$ of 8.2, for 7 days. The dashes are the data points, the horizontal 404 lines on each 'bean' show the means, and each 'bean' shape follows the general the distribution 405 of the data relative to density (constructed using the package 'beanplot' in R).

406 Figure 4. Montipora dissolution. The relationship between the surface area of the Montipora 407 coral skeletons $\left(\mathrm{cm}^{2}\right)$ and the loss of calcium carbonate $\left(\mathrm{CaCO}_{3}\right)(\mathrm{g})$ over 7 days follows the 408 equation loss $=-0.005 \times \exp 0017 *$ surface area . The dots are the data points, the thick, black line 409 represents the equation, and the dotted lines represent the $95 \%$ confidence intervals.

410 Figure 5. Pectinia dissolution. The relationship between the surface area of the Pectinia coral 411 skeletons $\left(\mathrm{cm}^{2}\right)$ and the loss of calcium carbonate $\left(\mathrm{CaCO}_{3}\right)(\mathrm{g})$ over 7 days.

412 Figure 6. Accretion potential of perforate corals and predicted sea-level rise. The projections of 413 expected rates of coral-reef accretion relative to rates of dissolution of reefs composed of mainly 414 perforate corals, with 3 different densities of corals (low, medium and high modeled as 1, 4, and $41510 \mathrm{~kg} \mathrm{CaCO}_{3} \mathrm{~m}^{-2} \mathrm{y}^{-1}$ ), along with projections of global sea-level rise (not considering regional 416 isostatic rebound effects, regional tectonics, and local land-use effects) and potential reef417 accretion rates from 1990 to 2100 following Vermeer and Rahmstorf (2009) for different IPCC 418 (2007) emission scenarios, where the $\mathrm{B} 1$ scenario is green and represents $\mathrm{a}+1.8^{\circ} \mathrm{C}$ global 419 increase in temperature; the $\mathrm{A} 2$ scenario is blue and represents a $+3.4^{\circ} \mathrm{C}$ global increase in 420 temperature; the $\mathrm{A} 1 \mathrm{~F} 1$ scenario is red and represents a $4^{\circ} \mathrm{C}$ global increase in temperature.

421 Figure 7. Accretion potential of imperforate corals and predicted sea-level rise. The projections 422 of expected rates of coral-reef accretion relative to rates of dissolution of reefs composed of 423 mainly imperforate corals, with 3 different densities of corals (low, medium and high modeled as 4241,4 , and $10 \mathrm{~kg} \mathrm{CaCO}_{3} \mathrm{~m}^{-2} \mathrm{y}^{-1}$ ), along with projections of global sea-level rise (as in Figure 6). 
425 Table 1. Porosity of scleractinian corals. Scleractinian coral families, the number of species in 426 each family, and the general porosity of the coral skeletons. Classifications were based on the 427 porosity of the colony walls, the coenosteum, and the collumellae at the scale of $1 \mathrm{~mm}^{2}$. There are 428 approximately 404 perforate species and 432 imperforate coral species, globally. 


\section{Table 1 (on next page)}

Porosity of scleractinian corals.

Scleractinian coral families, the number of species in each family, and the general porosity of the coral skeletons. Classifications were based on the porosity of the colony walls, the coenosteum, and the collumellae at the scale of $1 \mathrm{~mm}^{2}$. There are approximately 404 perforate species and 432 imperforate coral species, globally. 
2 Family

3 Acroporidae

4 Agariciidae

5 Astrocoeniidae

6 Caryophylliidae

7 Dendrophylliidae

8 Euphyllidae

9 Faviidae

10 Fungiidae

11 Meandrinidae

12 Merulinidae

13 Mussidae

14 Oculinidae

15 Pectiniidae

16 Pocilloporidae

17 Poritidae

18 Siderastreidae

19 Trachphylliidae
Number of species 271

45

15

7

19

17

130

46

12

12

52

16

29

31

101

32

Porosity

Perforate

Imperforate

Imperforate

Imperforate

Imperforate

Imperforate

Imperforate

Imperforate

Imperforate

Imperforate

Imperforate

Imperforate

Imperforate

Imperforate

Perforate

Perforate

Imperforate 


\section{Figure 1}

Figure 1. Montipora.

Scanning electron microscope image of Montipora skeleton; scale bar is 500 micrometer.

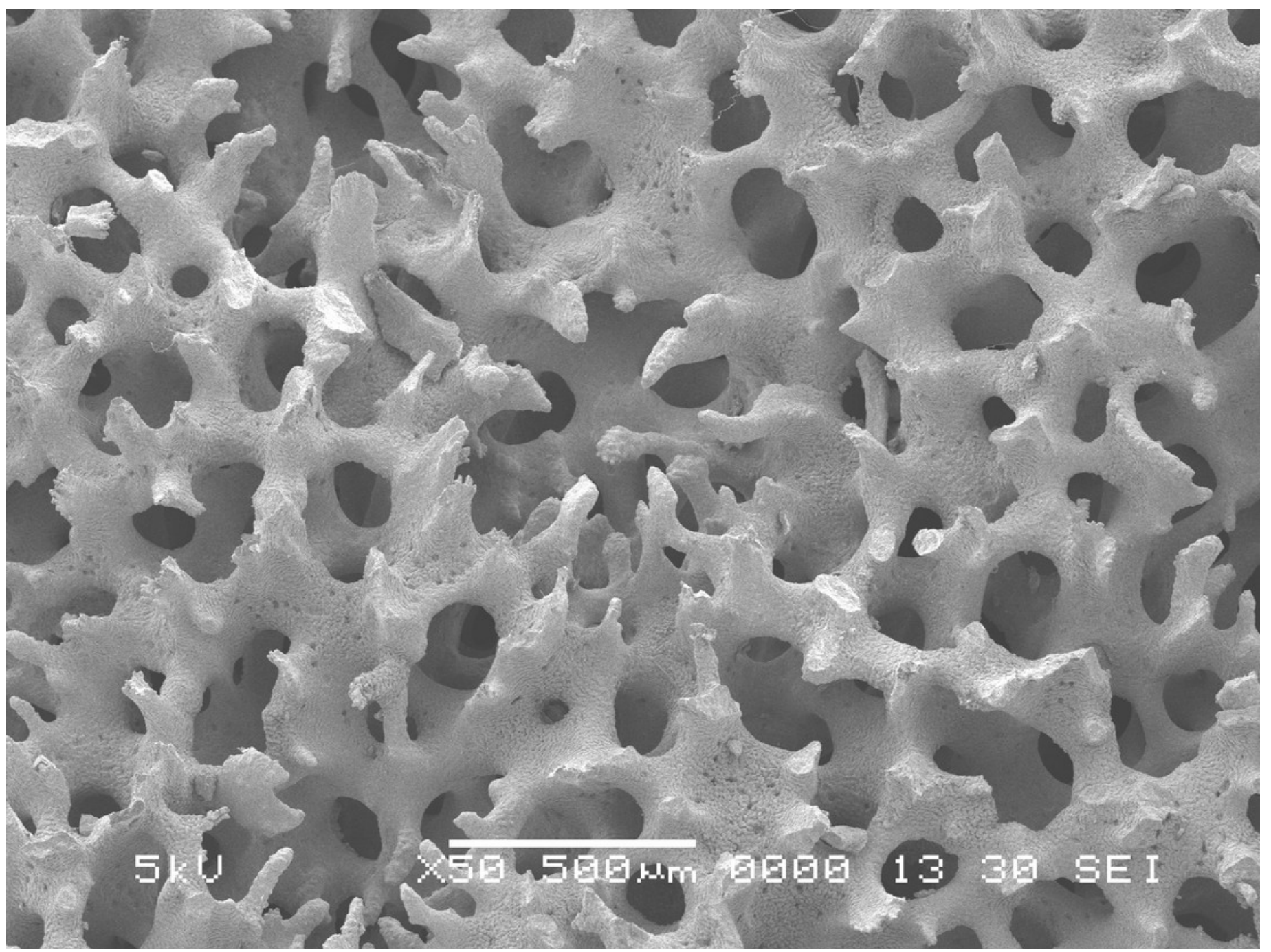




\section{Figure 2}

Figure 2. Pectinia.

Scanning electron microscope image of Pectinia skeleton; scale bar is 500 micrometer.

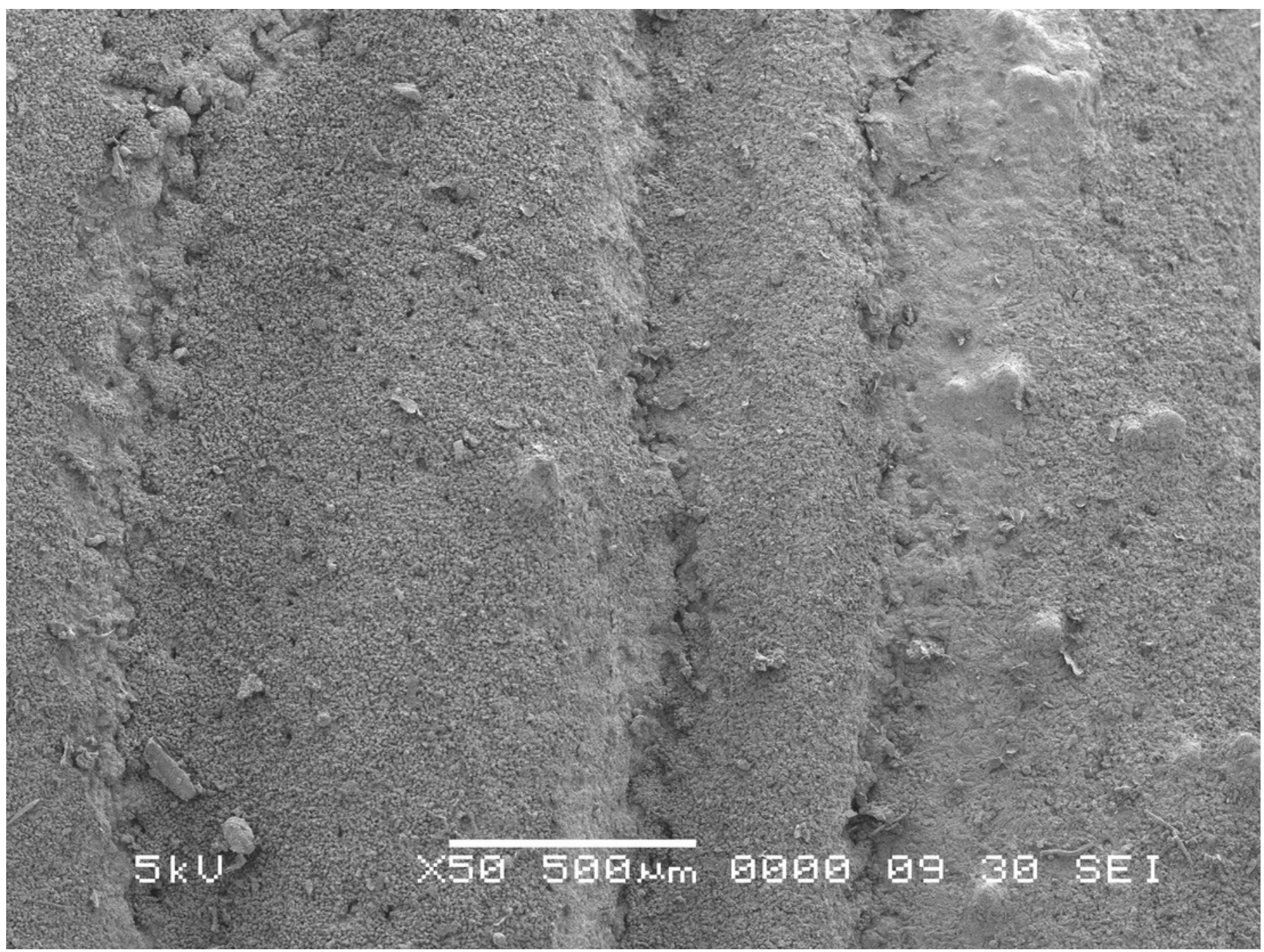




\section{Figure 3}

Figure 3. Comparative loss of calcium carbonate.

Loss of calcium carbonate, divided by the initial weight $(\mathrm{g})$, of four different coral growth forms of Montipora coral skeletons, and one growth form of Pectinia coral skeleton, when exposed to $\mathrm{pH} 7.8$ seawater for 7 days. The graph also depicts the controls for Montipora and Pectinia coral skeletons, which were exposed to present-day seawater, at a pH of 8.2, for 7 days. The dashes are the data points, the horizontal lines on each 'bean' show the means, and each 'bean' shape follows the general the distribution of the data relative to density (constructed using the package 'beanplot' in R).

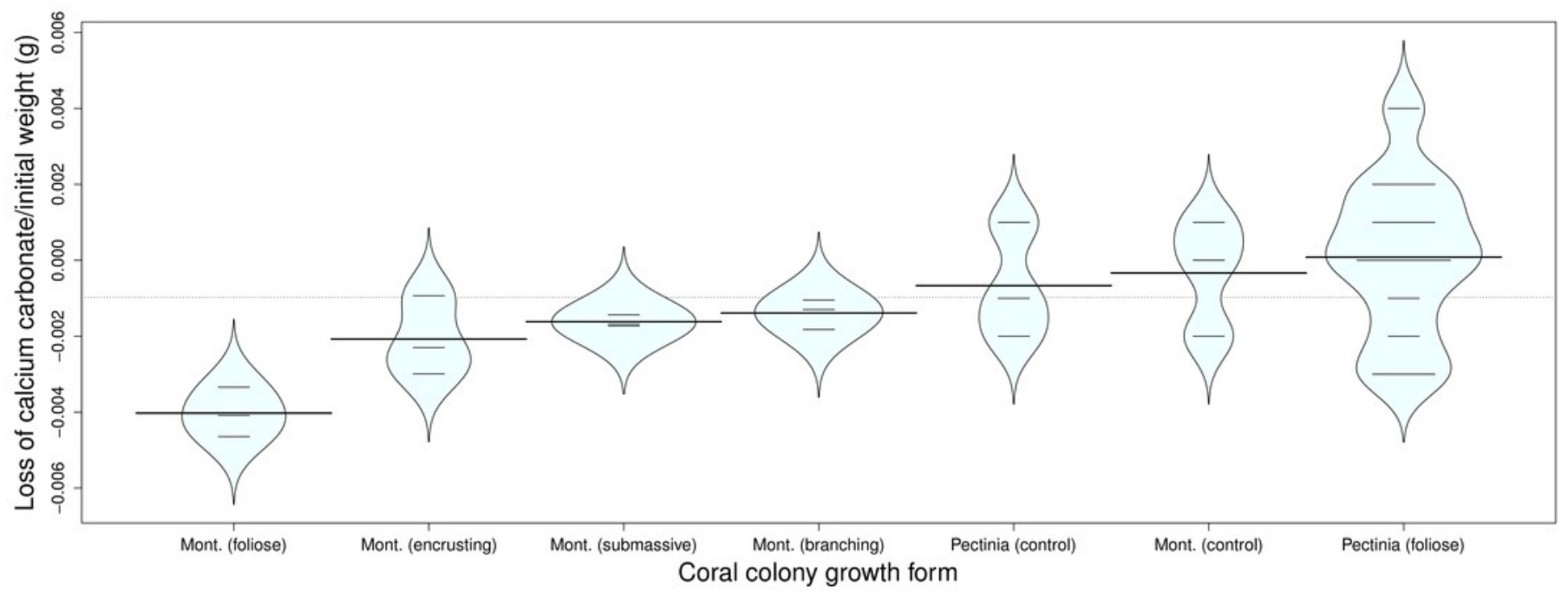




\section{Figure 4}

Figure 4. Montipora dissolution.

The relationship between the surface area of the Montipora coral skeletons $\left(\mathrm{cm}^{2}\right)$ and the loss of calcium carbonate $\left(\mathrm{CaCO}_{3}\right)(\mathrm{g})$ over 7 days follows the equation loss $=-0.005 \times \exp ^{0}$ 017 * surface area. The dots are the data points, the thick, black line represents the equation, and the dotted lines represent the $95 \%$ confidence intervals.

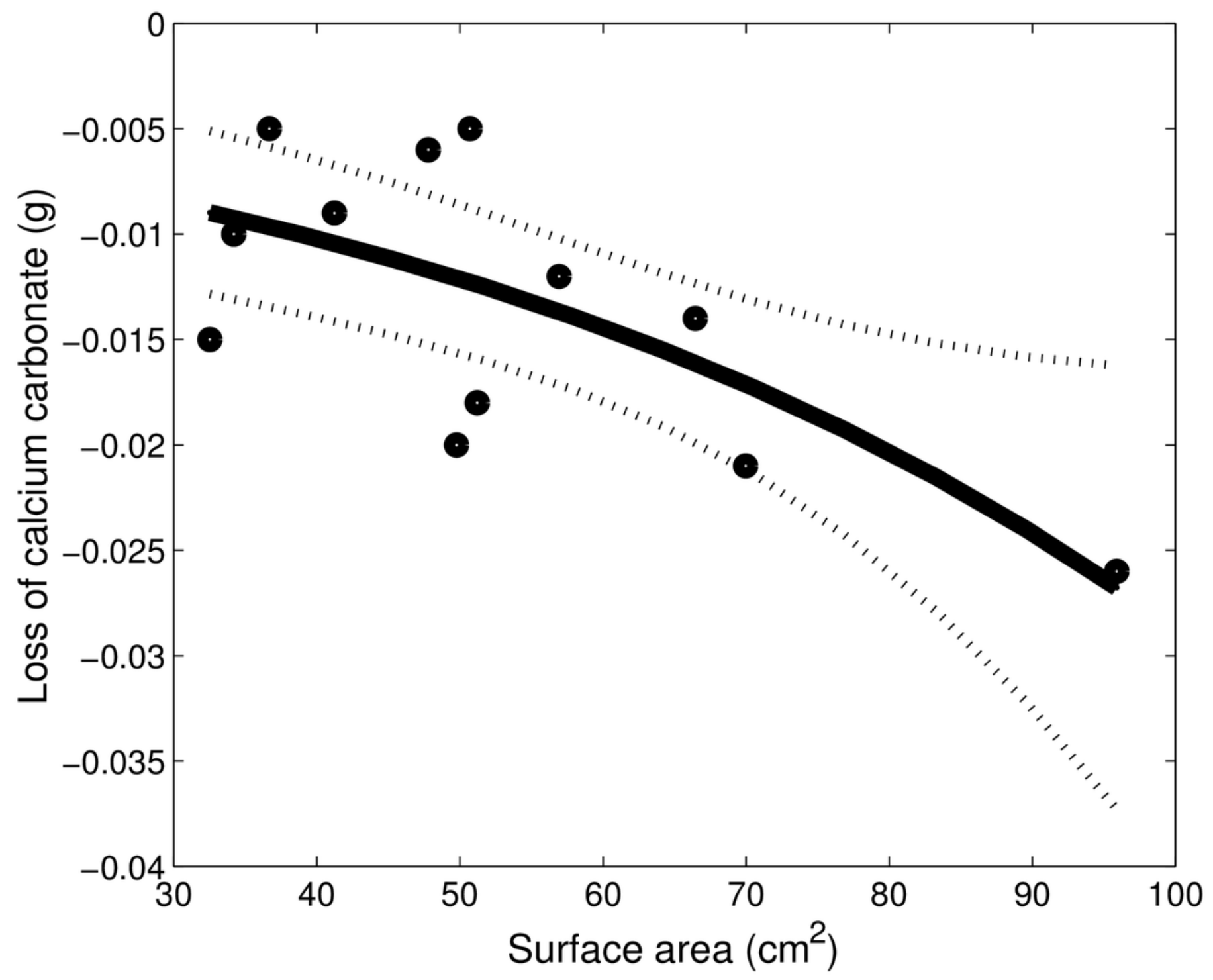




\section{Figure 5}

Figure 5. Pectinia dissolution.

The relationship between the surface area of the Pectinia coral skeletons $\left(\mathrm{cm}^{2}\right)$ and the loss of calcium carbonate $\left(\mathrm{CaCO}_{3}\right)(\mathrm{g})$ over 7 days.
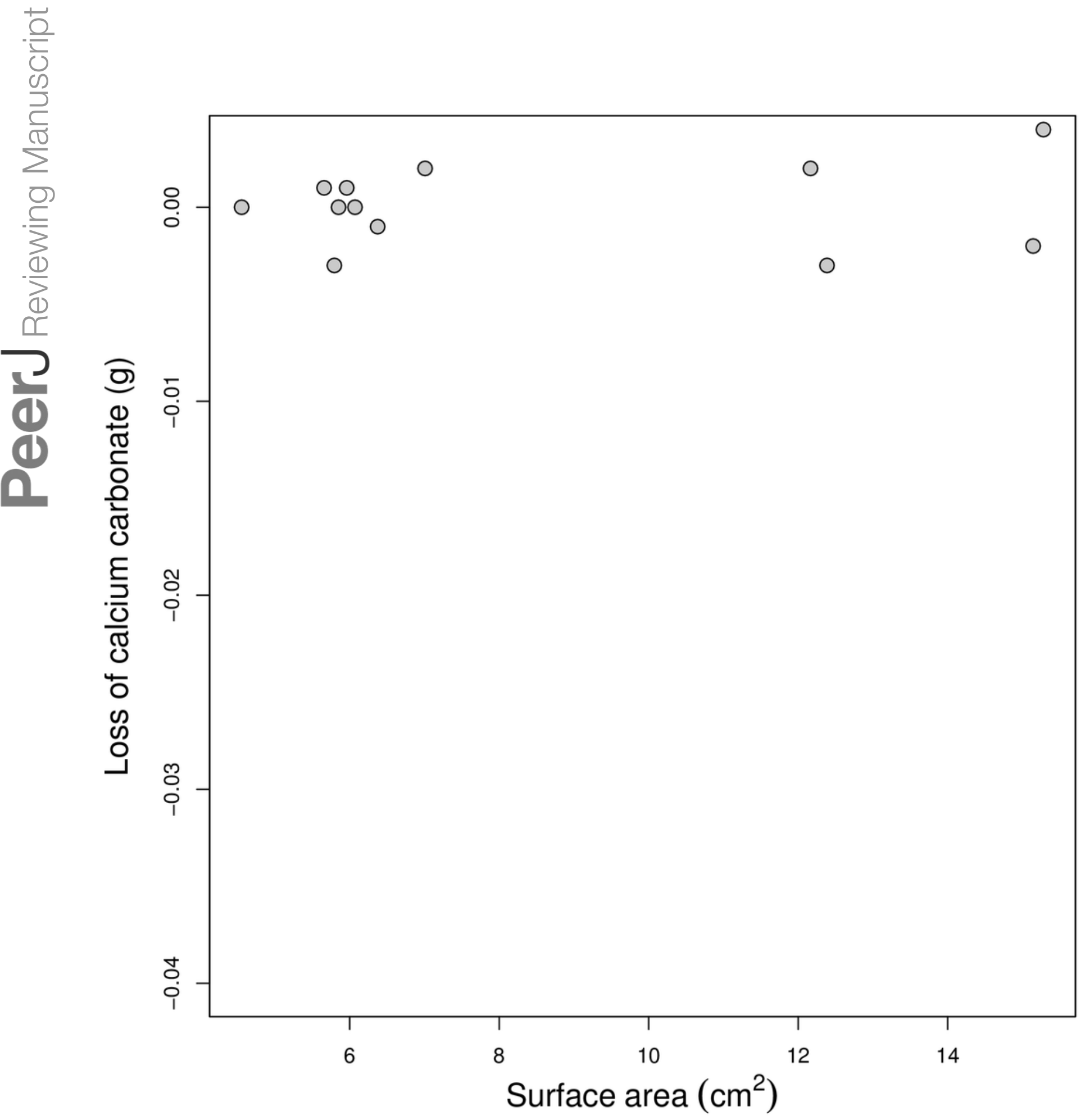


\section{Figure 6}

Accretion potential of perforate corals and predicted sea-level rise.

The projections of expected rates of coral-reef accretion relative to rates of dissolution of reefs composed of mainly perforate corals, with 3 different densities of corals (low, medium and high modeled as 1,4 , and $10 \mathrm{~kg} \mathrm{CaCO}_{3} \mathrm{~m}^{-2} \mathrm{y}^{-1}$ ), along with projections of global sealevel rise (not considering regional isostatic rebound effects, regional tectonics, and local land-use effects) and potential reef-accretion rates from 1990 to 2100 following Vermeer and Rahmstorf (2009) for different IPCC (2007) emission scenarios, where the B1 scenario is green and represents a $+1.8^{\circ} \mathrm{C}$ global increase in temperature; the $\mathrm{A} 2$ scenario is blue and represents a $+3.4^{\circ} \mathrm{C}$ global increase in temperature; the A1F1 scenario is red and represents a $40 \mathrm{C}$ global increase in temperature.

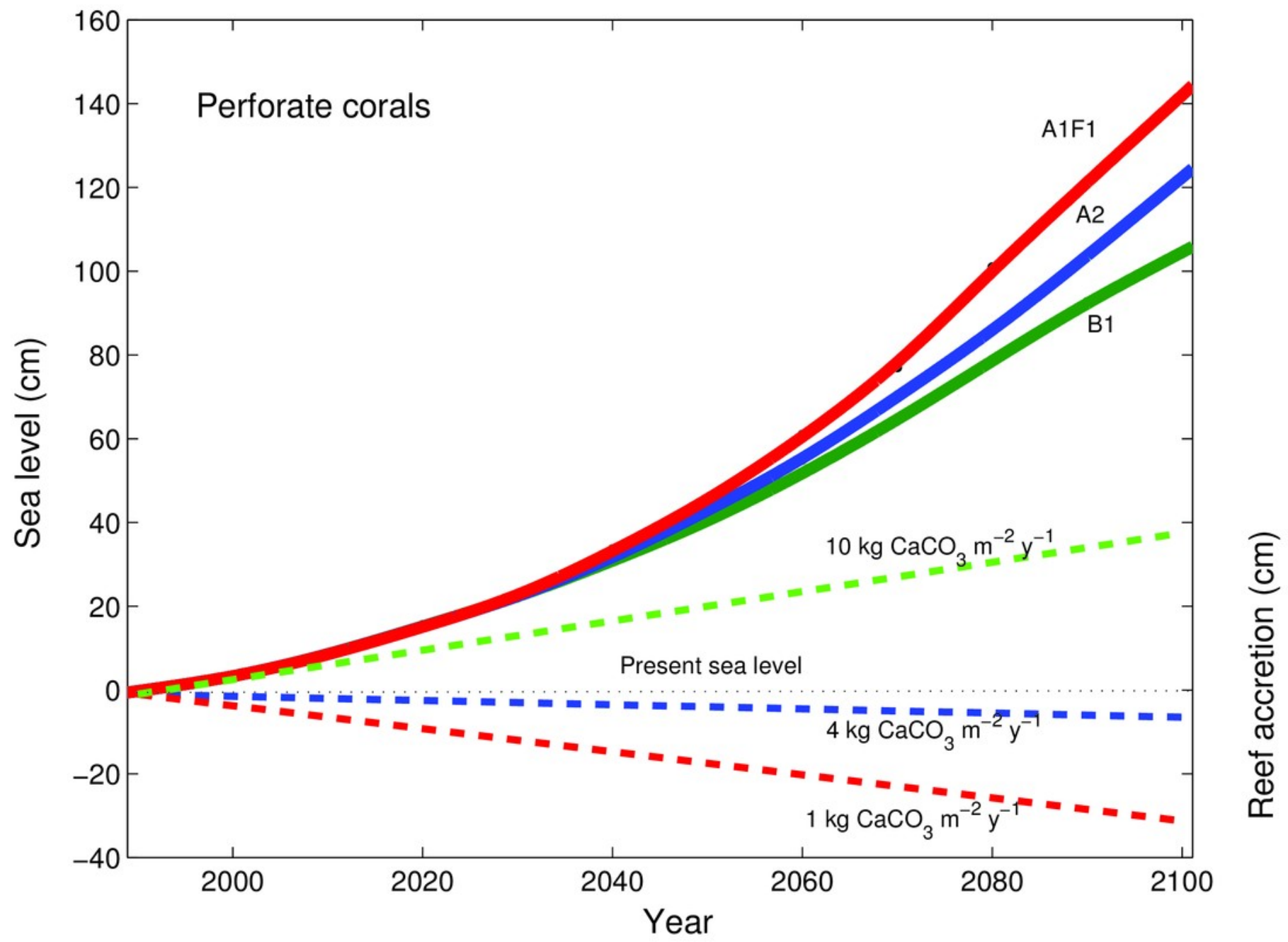




\section{Figure 7}

Accretion potential of imperforate corals and predicted sea-level rise.

The projections of expected rates of coral-reef accretion relative to rates of dissolution of reefs composed of mainly imperforate corals, with 3 different densities of corals (low, medium and high modeled as 1,4 , and $10 \mathrm{~kg} \mathrm{CaCO}_{3} \mathrm{~m}^{-2} \mathrm{y}^{-1}$ ), along with projections of global sealevel rise (as in Figure 6).

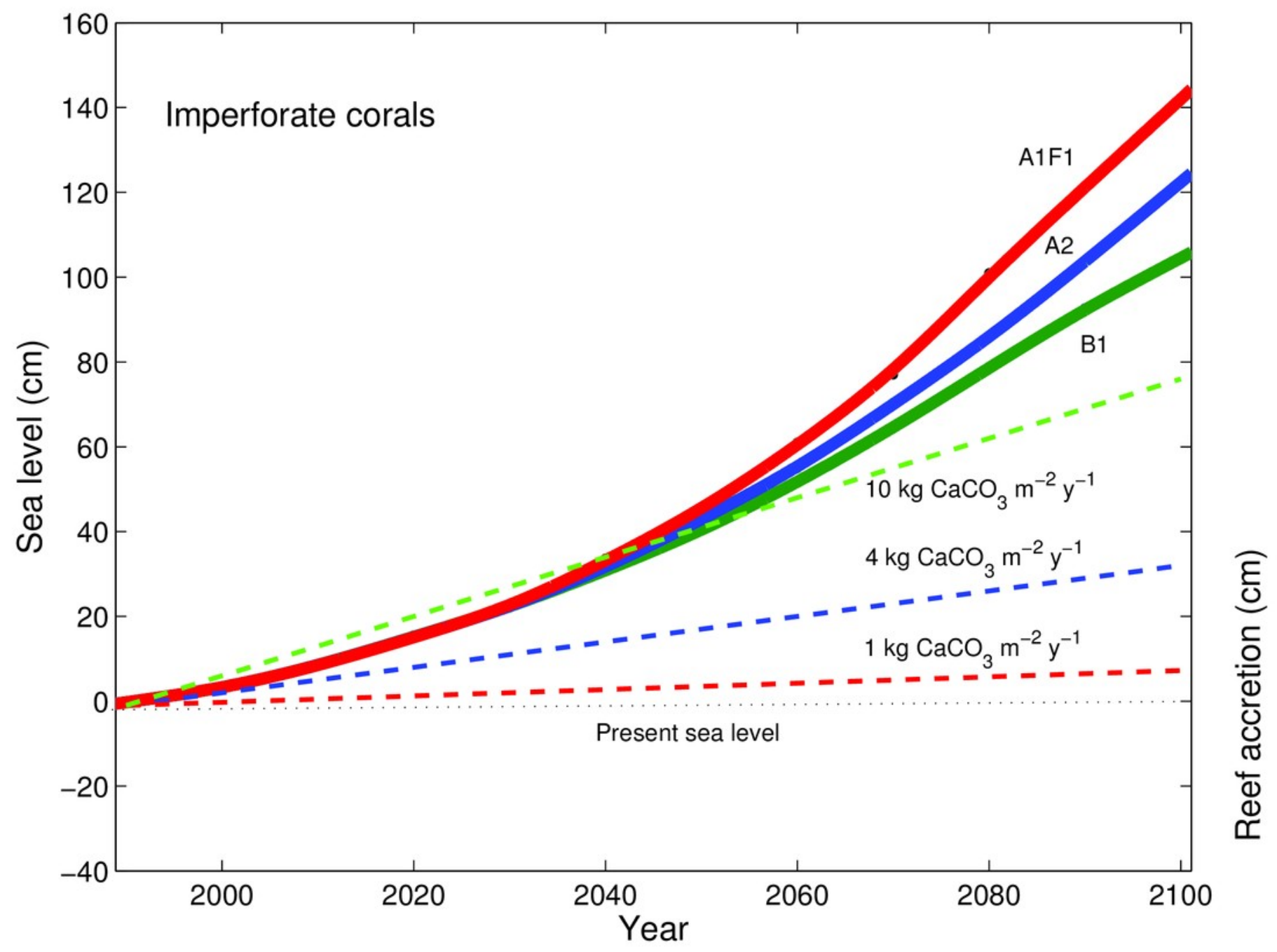

